\title{
PEMIKIRAN FAZLUR RAHMAN DALAM KAJIAN QUR'AN-HADIS (TELAAH KRITIS)
}

\author{
Oleh : \\ Anas Rohman \\ Rohman_anas2@yahoo.com
}

\begin{abstract}
Fazlur Rahman is one of the new innovators in Islam that had a great influence in the 20th century, especially in Pakistan, Malaysia, Indonesia, and other countries (Islamic countries), and Chicago America (western countries) who had various thoughts related to problem. He succeeded in thinking critically both Islam and Western traditions. He succeeded in developing methods that could provide alternative solutions to contemporary Muslims. Rahman's thoughts contributed a lot to the development of Islamic studies, especially in the study of the Qur'an-Hadith. the historicalsociological approach above will create a new, dynamic, and creative discourse so that the moral ideal of the Prophet's sunnah. can be realized progressively in a variety of social phenomena and problems, so that the hadith is no longer static but becomes a living sunnah.
\end{abstract}

Keywords: Thought, Fazlur Rahman, Qur'anic Hadith.

\begin{abstract}
Abstrak
Fazlur Rahman adalah salah satu inovator baru dalam Islam yang memiliki pengaruh besar di abad 20, terutama di Pakistan, Malaysia, Indonesia, dan negara-negara lain (negara-negara Islam), dan Chicago America (negara barat) yang memiliki berbagai pemikiran terkait dengan masalah. Ia sukses berpikir kritis baik Islam maupun tradisi Barat. Ia berhasil mengembangkan metode yang bisa memberikan solusi alternatif terhadap Muslim kontemporer. Pemikiran Rahman banyak memberikan sumbangsih terhadap perkembangan kajian Islam, khususnya dalam kajian Qur'an-Hadis. pendekatan historis-sosiologis di atas akan menciptakan wacana yang baru, dinamis, dan kreatif sehingga ideal moral dari sunnah Nabi Saw. dapat direalisasikan secara progresif di dalam aneka ragam fenomena dan permasalahan sosial, sehingga hadis tidak lagi statis melainkan menjadi sunnah yang hidup.
\end{abstract}

Kata kunci : Pemikiran, Fazlur Rahman, Qur’an Hadis 


\section{A. PENDAhULUAN}

Berkembangnya kehidupan sosial menuntut para pemikir dalam studi Qur'an dan Hadis agar selalu mengembangkan metodologinya guna menuangkan gagasan baru sehingga mampu diaktualisasikan dalam kehidupan sekarang. Pemahaman Qur'an maupun Hadis harus selalu berkembang dan mengikuti kondisi sosial masyarakat luas. Salah satu pemikir/cendekiawan Muslim dalam kajian metodologi tafsir Qur'an dan Hadis adalah Fazlur Rahman.

Pemikiran Fazlur Rahman diawali dari pergolakan hebat yang terjadi antara Muslim India dan Pakistan dalam potensi intelektual dan politiknya yang terjadi selama kurang lebih satu abad. Yakni sejak permulaan abad kesembilan belas hingga pertengahan abad kedua puluh, tepatnya berawal dari pemikiran modern Sir Sayid Ahmad Khan (18171898) hingga Abu al-A'la al-Maududi (1903-1983). Pada abad kesembilan belas, umat Islam India hidup dengan tradisi kebesaran dan kemegahan masa lalu. Akan tetapi pada abad kedua puluh sebagian rakyat Muslim India dengan visi dan campur aduk antara kebesaran masa lalu yang telah hilang dan impian kebesaran yang akan datang. Hal ini mendorong Rahman untuk menyumbangkan pemikiran bagi masyarakat luas.

Pemikiran Islam Rahman tampil sebagai sosok yang meyakinkan dalam merumuskan metode penafsiran Quran. Orisinalitas metode penafsiran yang dirumuskan terletak pada digunakannya filsafat, ilmuilmu sosial dan humaniora. Fazlur Rahman mengkritisi bahwa metode penafsiran klasik cenderung menggunakan pendekatan secara terpisahpisah, sehingga mengakibatkan munculnya persoalan baru. Dalam kajian hadis, Rahman menggunakan pendekatan historis-sosiologis agar mampu menciptakan nuansa yang baru, dinamis, dan kreatif sehingga pesan 
moral dari Sunnah Nabi dapat direalisasikan secara progresif untuk menjawab tantangan perubahan zaman.

Latar belakang di atas, membantu dan menggugah semangat untuk mengkaji lebih dalam pemikiran Fazlur Rahman dalam kajian Qur'an-hadis dan urgensinya bagi kehidupan zaman sekarang. Berdasarkan latar belakang tersebut, maka rumusan masalah makalah ini sebagai berikut: 1. Bagaimana biografi Fazlur Rahman? 2. Bagaimana corak pemikirannya dalam memahami Qur'an? 3. Bagaimana corak pemikirannya dalam memahami Hadis? 4. Apa konstribusi Fazlur Rahman dalam kajian Qur'an-Hadis?

\section{B. PEMBAHASAN}

\section{Fazlur Rahman}

Fazlur Rahman adalah salah satu inovator baru dalam Islam yang memiliki pengaruh besar di abad 20, terutama di Pakistan, Malaysia, Indonesia, Chicago America (negara barat) dan negara-negara lain (negara-negara Islam) yang memiliki berbagai pemikiran terkait dengan masalah kontemporer. Ia sukses berpikir kritis baik pemikiran seputar Islam maupun tradisi Barat. Ia berhasil mengembangkan metode yang bisa memberikan solusi alternatif terhadap Muslim kontemporer terutama dalam kajian Qur'an-Hadis dan prosedur rumusannya. ${ }^{1}$

Fazlur Rahman di lahirkan pada hari minggu 21 September 1919 M, disebuah daerah yang bernama Hazra barat laut Pakistan. Ayahnya bernama Maulana Syahab al-Din. Ia dibesarkan dalam sebuah lingkungan keluarga Muslim yang taat dan mempraktekkan ajaran fundamental Islam seperti, shalat, puasa dan sebagainya. Semasa

\footnotetext{
${ }^{1}$ Mirawati, "Thinking Of Fazlur Rahman About Islamic Education" Al-Manar Journal Of Education And Islamic Studies (2014), 82, diakses 17 Maret 2018.
} 
kecilnya, Rahman dibesarkan dalam sebuah keluarga religius berbasis madzab Hanafi' sebuah madzab sunni ${ }^{2}$ yang bercorak lebih rasionalistik dibandingkan tiga madzab sunni lainnya yaitu Maliki, Syafii, dan Hanbali. Ia mendapatkan pendidikan agama secara inten dari kedua orang tuanya sehingga di usia sepuluh tahun ia mampu menghafal al Quran di luar kepala. Ia juga sudah trampil dan terbiasa melaksanakan salat, puasa, tanpa pernah meninggalkannya. Dari ayahnya, Maulana Shihab al-Din, ia banyak mendapatkan pendidikan kajian bidang tafsir dan hadis. Sedangkan selama bergaul dengan ibunya, Rahman mendapatkan pelajaran berharga tentang nilai-nilai kebenaran, cinta kasih, dan kesetiaan. ${ }^{3}$

Meskipun ia dibesarkan dalam tradisi mazhab Hanafi, sejak umur belasan tahun ia telah mengembangkan pemikirannya secara bebas. Sejak kecil ia telah bersikap skeptis terhadap pelajaran Hadis yang diberikan ayahnya. Sikap tersebut barangkali merupakan warisan Ahmad Khan dan gerakan Aligarh-nya kepada modernisme Islam yang belakangan di kembangkan oleh Rahman, serta disusunnya secara sistimatis dalam karya-karya intelektualnya. ${ }^{4}$

Rahman memang tidak seperti ayahnya yang belajar di Darul Ulum. Meski demikian, ia menguasai ilmu Darsenizami yang

\footnotetext{
${ }^{2}$ Madzab sunni atau dikenal juga dengan sebuan ahlu Sunnah wa al-Jama'ah adalah madzab yang senantiasa mengikuti jalan hidup Rasulullah dan jalan hidup para sahabatnya. Dalam kajian fiqh madzab ini sejalan dengan subsansi ajaran empat madzab besar dalam Islam yakni madzab Hanafi (Abu Hanifah 80-150 H), Madzab Maliki (Malik bin Anas 90-179 H), Madzab Syafi'I (Muhammad bin Idris asy-Syafi'I 150-204), Madzab Hambali (Ahmad bin Hanbal 164-41). (Sahilun A Nasir, Pemikiran Kalam Teologi Islam, (Jakarta: Raja Grafindo Persada, 2010), hlm. 196.

${ }^{3}$ Rahman, Fazlur, Cita-cita Islam. Terjemahan Sufyanto dan Imam Musbikin. (Yogyakarta: Pustaka Pelajar, 2000) hlm. 4.

${ }^{4}$ Ajahari, "Pemikiran Fazlur Rahman Dan Muhammad Arkoun” Jurnal Sudi Agama dan Masyarakat, (2016), 238-239, diakses: 17 Maret 2018.
} 
ditawarkan di madrasah tersebut melaui kajian privat dengan ayahnya. Hal ini akan jelas memengaruhi Rahman dalam memahami Islam traditional. Ketika Rahman berusia 14 tahun (1933 M), keluarganya hijrah ke Lahore, kota Rahman menerima pendidikan modern. Pada tahun 1940 M, ia menyelesaikan Sarjana Muda (B.A) dalam jurusan Bahasa Arab di Universitas Punjab. Dua tahun kemudian ia memperoleh gelar Master of Art (M.A.) dalam jurusan dan universitas yang sama. 5 Ketidakpuasan Fazlur Rahman terhadap mutu pendidikan tinggi Islam di India yang dipandangnya ketika itu sangat rendah, menyebabkan Rahman memutuskan untuk melanjutkan studinya di Barat. Pada tahun 1946 M, ia memutuskan untuk melanjutkan studi pada program doctor (Ph.D Program) di Universitas Oxford, Inggris. Pada program ini Rahman berkonsentrasi pada kajian Filsafat Islam. Ia menyelesaikan studi Doktornya dalam waktu 3 tahun (1946-1949) dengan disertasi yang berjudul Avicenna's Psychology di bawah bimbingan Profesor S. Van den Berg dan H A R Gibb. ${ }^{6}$

Setelah menyelesaikan pendidikannya di Oxford Inggris, Rahman masih menetap di Negara tersebut. Karir Rahman dimulai dengan menjadi dosen Studi Persia dan Filsafat Islam di Universitas Durham dari 1950-1958. Pada tahun 1958, ia diangkat sebagai Associate Professor di Institut Islam Studi, McGill University di Montreal, di mana dia tinggal sampai tahun 1961.

${ }^{5}$ Rifki Ahda Sumantri, "Hermeneutika al-Qur'an Fazlur Rahman Metode Tafsir Doubel Movement" Jurnal Komunika, (2015), 4, diakses: 17 Maret 2018, doi: 10.24090/kom.v7i1.2013.pp\%p.

${ }^{6}$ Amal, Islam Dan Tantangan Modernitas Studi Pemikiran Hukum Fazlur Rahman, Bandung: Penerbit Mizan, 1993. 81. 
Di samping jabatan-jabatan tersebut, Rahman juga ditunjuk sebagai Direktur Lembaga Riset Islam dan pada tahun 1961 juga dan sebagai anggota dewan penasehat ideologi islam pemerintahan Pakistan. Melalui dua lembaga tersebut, Rahman terlibat secara intensif dalam upaya mereinterpretasikan Islam menjadi idiom-idiom atau istilah-istilah yang rasional dan ilmiah untuk memenuhi kebutuhan masyarakatnya. Namun, gagasan pembaharuan yang dirancangkannya tidak lazim dan berlawanan dengan opini-opini para tradisionalis dan fundamentalis, sehingga gagasan-gagasannya mendapat tantangan-tantangan yang keras dan menimbulkan kontroversi-kontroversi yang tidak berkesudahan. Berbagai kontroversi ini dilatar belakangi juga oleh ketidak sukaan kalangan ulama atas penunjukan Rahman untuk terlibat di dua lembaga tersebut, di samping itu kolaborasi Rahman dengan Ayyub Khan juga tidak menguntungkan. Keberaantan-keberatan yang ditunjukkan terhadap gagasan Rahman sebenarnya merupakan tantangan terselubung terhadap rezim Ayyub Khan. ${ }^{7}$

Dirasa berada pada posisi yang tidak menguntungkan, pada tanggal 5 september 1968 Rahman mengajukan pengunduran diri dari jabatan Direktur Lembaga Riset. Kemudian pada tahun 1969, ia juga mengundurkan diri dari keanggotaan Dewan Penasehat Ideologi Negara. Rahman dianggap memiliki pemikiran-pemikiran radikal sehingga membuatnya dikritik oleh masyarakat Pakistan, dan karena itu pula ia memilih untuk meninggalkan Pakistan. Setelah meninggalkan Pakistan, pada tahun 1969 ia diangkat sebagai Profesor Pemikiran Islam di Universitas Chicago dan pada tahun 1987

${ }^{7}$ Sa'dullah Assa'idi, Pemahaman Tematik al-Qur'an Menurut Fazlur Rahman, (Jakarta: Pustaka Pelajar, 2013), hlm. 46-47. 
Universitas tersebut membuatnya menjadi Harold $H$. Swift Distinguished Service Profesor sebagai pengakuan atas kontribusinya terhadap beasiswa. Dan ia meninggal pada tanggal 26 Juli $1988 .^{8}$

Rahman merupakan seorang pemikir dalam berbagai kajian ilmu, diantara buku-buku yang telah ia tulis di antaranya: Avicenna's Psychology (1952), Prophecy in Islam (1958), Ibn Sina, De Anima (Arabic Text) (1959), Islamic Methodology in History (1965), Islam (1966), Philosophy of Mulla Sadra Shirazi (1975), Major Themes of the Qur'an (1980), Islam and Modernity: Transformation of an Intellectual Tradition (1982), Health and Medicine in Islamic Tradition (1987). Selain tulisan yang dibukukan, Rahman juga banyak menulis artikel-artikel Islam. ${ }^{9}$

\section{Corak Pemikiran}

Biografi intelektual Rahman menunjukkan bahwa ia berada pada dua pola pemikiran yang berbeda yakni corak pemikiran barat dan tradisional. Pertama, latar belakang pendidikan tradisional di bagian timur Pakistan dan latar belakang pendidikan modern Barat Inggris. Kedua, kombinasi latar belakang karir intelektual bersama pihak konservatif di Pakistan dan latar belakang intelektual bersama pihak liberal di Chicago. Dari kedua latar belakang yang berbeda tersebut melahirkan pemikiran Rahman yang moderat, sintesis dan metodis.

Bagi Rahman sangatlah penting mengartikan wahyu dalam kajian sejarah, sebab jika sejarah berpengaruh dalam memahami wahyu yang transenden, maka penting untuk menyelidiki keberadaan wahyu. Kemudian Rahman menunjukkan bagaimana otoritas Qur'an

\footnotetext{
${ }^{8}$ Fazlur Rahman, Major Themes of the Qur'an, PDF-BOOK (Chichago: minneoapolis-Biblioeca Islamica, 1980), hlm. ii

${ }^{9}$ Fazlur Rahman, Islamic Methodology in History, (Pakistan: Islamic Research Institute's, t.t), hlm. ii
} 
dan Hadis hadir di tengah-tengah realitas sejarah dan buadaya di masyarakat. ${ }^{10}$ Rahman dalam memahami Qur'an, lebih mendahulukan prinsip moral Qur'an dari pada lahiriyah teks meskipun ia tidak meninggalkan teks sama sekali.

Berdasarkan warisan intelektual Islam pada masa awal, Rahman berusaha memberikan teori kompleks yang menghubungkan wahyu dengan alasan-alasan filosofis, psikologis, sosisologis, dan antropologis.

\section{Qur'an Menurut Pandangan Fazlur Rahman}

\section{Qur'an}

Sifat Qur'an yang bersifat historis menyebabkan munculnya gagasan dan teori hermeneutika (metode penafsiran). Teori ini menjadi kerja usaha yang sangat mendesak untuk dikembangkan dalam memahami makna Qur'an secara utuh. Harapannya, bagianbagian teologis dan etika legalnya dapat ditempatkan dalam keseluruhan (totalitas) yang padu.

Rahman memahami Qur'an sebagai wahyu dan karir kenabian Muhammad yang berlangsung selama lebih dari dua puluh dua tahun. Selama periode itu semua jenis keputusan baik kebijakan dalam perdamaian dan perang maupun legal dan isu moral dibuat di hadapan situasi aktual. Qur'an berasal dari zaman pewahyuannya merupakan aplikasi praktis dan politis dan tidak hanya teks renungan atau pietistik pribadi Muhammad. Demikian isi dan kangdungannya

\footnotetext{
${ }^{10}$ Ilyas Supena, Desain Ilmu-ilmu Keislaman dalam Pemikiran Hermeneutika Fazlur Rahman, (Semarang: Walisongo Press, 2008), hlm. 51.
} 
juga diarahkan pada perbaikan moral manusia dalam arti konkret dan komunal, bukan menuju pribadi dan metafisik. ${ }^{11}$

Rahman dalam bukunya yang berjudul "Islam" memahami Qur'an sebagai sebuah kitab yang berisi prinsip-prinsip keagamaan dan moral serta anjuran-anjuran, dan bukan sebagai suatu dokumen hukum di Negara Madinah. Pengembangan konsep tentang Tuhan, pencipta mutlak alam semesta yang di dalamnya terdapat sifat-sifat kreatif. Perintah maupun anugrah-anugrah yang dituangkan dalam Qur'an satu sama lain merupakan suatu hal yang saling memengaruhi. ${ }^{12}$ Hal tersebut menunjukkan bahwa segala sesuatu yang berhubungan dengan manusia dan alam selalu berhubungan dengan Qur'an. Sebagaimana Qur'an sendiri secara bertahap mengungkapkan pandangannya dengan lebih lengkap mengenai tata moral bagi manusia. Tidak ada keraguan bahwa tujuan utama Qur'an adalah membangun sebuah sosial yang layak bagi ketertiban di bumi yang akan berbasis etis dan adil.

\section{Teori Dobel Movement}

Rahman mengkritisi bahwa metode penafsiran klasik cenderung menggunakan pendekatan dalam menginterpretasikan al-Qur'an secara terpisah pisah dan sepotong-sepotong, sehingga mengakibatkan persoalan yang dihadapi bukannya selesai, tetapi justru menimbulkan persoalan baru. 1982), hlm.

${ }^{11}$ Fazlur Rahman, Islam and Modernity, PDF BOOK (London: Chicago press,

${ }^{12}$ Fazlur Rahman, Islam, terj. Seonaji Saleh, (Jakarta: PT Bumi Aksara, 1992), hlm. 58. 
Rahman mendasarkan bangunan hermeneutikanya pada konsepsi teoritik bahwa yang ingin dicari dan diaplikasikan dari Quran di tengah-tengah kehidupan manusia adalah bukan pada kandungan makna literalnya tetapi lebih pada konsepsi pandangan dunianya (weltanschaung). ${ }^{13}$ Berkaitan dengan pemikirannya dalam memahami Qur'an, Fazlur Rahman memiliki metodologi memahami Qur'an yang dikenal dengan teori Double Movement. ${ }^{14}$ Double movement adalah metode penafsiran yang memuat di dalamnya 2 (dua) gerakan, gerakan pertama berangkat dari situasi sekarang menuju ke situasi masa al-Qur'an diturunkan dan gerakan kedua kembali lagi, yakni dari situasi masa al-Qur'an diturunkan menuju ke masa kini, yang ini akan mengandaikan progresivitas pewahyuan.

Gerakan pertama yakni dari situasi sekarang ke masa Qur'an diturunkan. Untuk memahami ini, terdiri dari dua langkah kerja: Pertama,pemahaman arti atau makna suatu pernyataan dengan mengkaji situasi atau problem historis dimana pernyataan Qur'an tersebut merupakan jawabannya. Sebelum memahami ayat-ayat spesifik dalam sinaran situasi-situasi spesifiknya maka perlu dipahami kehidupan menyeluruh di Arab pada saat turunnya ayat dalam batasan-batasan agama dan adat istiadat masyarakat tersebut. Kedua, menggeneralisasikan jawaban-jawaban spesifik itu dan menyatakan sebagai pernyataan-pernyataan yang memiliki tujuan-

\footnotetext{
${ }^{13}$ Ulya, "Hermeneutika Double Movement Fazlur Rahman Menuju Peneapan Hukum Bervisi Etis", Jurnal Ulul Albab (2013), 9-10, diakses: 16 Maret 2018, doi: 10. 18860/ua.v0I0.2385

${ }^{14}$ Metode ini memberikan pemahaman yang sistematis dan kontekstualis, sehingga menghasilkan suatu penafsiran yang tidak atomistik, literalis dan tekstualis, melainkan penafsiran yang mampu menjawab persoalan-persoalan kekinian. Adapun yang dimaksud dengan gerakan ganda adalah: dimulai dari situasi sekarang ke masa Al-Qur'an diturunkan dan kembali lagi ke masa kini. (Fazlur Rahman, Islam and Modernitas: Tranformation of An Intellectual Tradition, (Chicago and London: Univercity Press, 1982), hlm. 6.
} 
tujuan moral-sosial umum yang dapat disaring dari teks-teks spesifik dalam sinaran latarbelakang sosio historis dan ratio logis (illat hukum) yang sering dinyatakan. ${ }^{15}$

Gerakan kedua, dari masa Qur'an diturunkan (setelah menemukan prinsip-prinsip umum) kembali lagi ke masa sekarang. Dalam pengertian bahwa ajaran-ajaran (prinsip) yang bersifat umum tersebut harus ditubuhkan dalam konteks sosio historis yang kongkret di masa sekarang. Untuk itu perlu dikaji secara cermat situasi sekarang dan dianalisa unsur-unsurnya sehingga situasi tersebut dapat dinilai dan diubah sejauh yang dibutuhkan serta ditetapkan prioritas-prioritas baru demi mengimplementasikan nilai-nilai Al-Qur'an secara baru pula. Gerakan kedua ini juga akan berfungsi sebagai pengoreksi dari hasil pemahaman dan penafsiran yang dilakukan pada gerakan pertama. ${ }^{16}$

Struktur hermeneutika double movement ${ }^{17}$

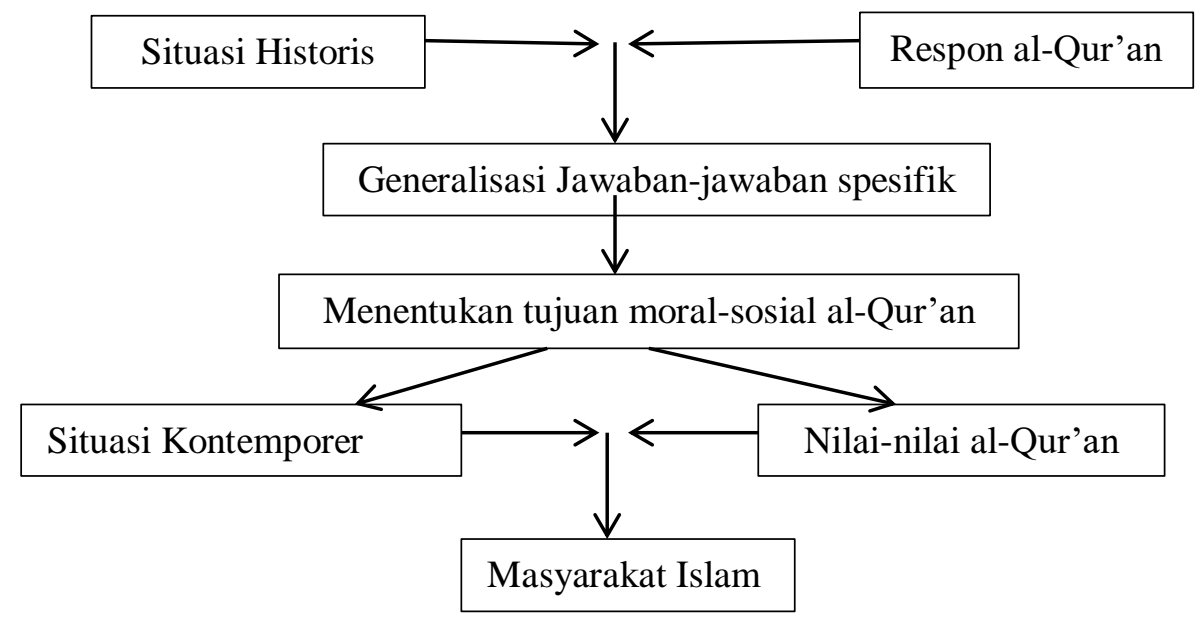

${ }^{15}$ Mawardi, "Hermeneutika al-Qur'an Fazlur Rahman” dalam Hermeneutika alQur'an dan Hadis, (Yogyakarta: eLSAQ, 2010), hlm. 71.

${ }^{16}$ Ahmad Syukri Sholeh, Metodologi Tafsir Al-Qur'an Kontemporer dalam Pandangan Fazlur Rahman, (Jakarta: Gaung Persada Press, 2007), hlm. 132. hlm. 182 .

${ }^{17}$ Abdul Mustaimtaqim, Epistemologi Tafsir Kontemporer, (Jakarta: LKiS, 2010), 
Inti pemikiran Rahman di atas adalah merumuskan visi etika Quran yang utuh sebagai prinsip umum dan kemudian menerapkan prinsip umum tersebut dalam kasus-kasus khusus yang muncul pada situasi sekarang. Gagasan Rahman yang demikian itu memiliki keunggulan karena peluang untuk mewadahi dan memberikan dasar solusi terhadap berbagai problem-problem khusus menjadi sangat terbuka. Apalagi ketika kita menengok watak wilayah teks yang terbatas, sedangkan wilayah permasalahan yang tak terbatas.

Untuk memahami dan mengaplikasikan metode di atas tersebut, perlu pemahaman dan pengetahuan sebagai berikut: Pertama, pengetahuan yang menyangkut bukan saja Bahasa Arab, melainkan juga kebiasaan-kebiasaan Bangsa Arab pada masa Nabi yang diperlukan untuk memahami al-Qur'an secara layak dengan kondisinya. Kedua, pemahaman latar belakang turunnya wahyu alQur'an yang disebut Asbabun nuzul, Ketiga, hadis kesejarahan yang memuat mengenai laporan-laporan mengenai bagaimana orang-orang dapat memahami perintah-perintah dn pernyataan-pernyataan alQur'an ketika pertama kali turun. ${ }^{18}$ Setelah memahami tiga hal tersebut, tiba gilirannya makna al-Qur'an dapat dipahami berdasarkan konteks perkembangan zaman dengan berdasar pada tonggak penafsiran-penafsiran terdahulu.

\footnotetext{
${ }^{18}$ Fazlur Rahman, Islam terj. Senoaji Saleh, hlm. 63.
} 
Rahman menyadari bahwa pendekatan sosio-historis dalam memahami wahyu di atas akan memunculka pertanyaan teologi yang serius, yakni tentang keabadian keabadian kalam Allah dan hukumhukum-Nya. Mengenai keabadian kalam Allah, menurutnya secara substansial dapat diakui. Adapun mengenai keabadian teks hokum, sepanjang mengenai pengaturan sosial Tuhan memiliki rencana moral dan hokum yag diyatakan secara spesifik.

Tidak semua ayat dapat dipahami dengan teori Double Movement. Teori ini hanya dapat diterapkan pada kasus-kasus yang bisa ditemukan teksnya dalam Qur'an maupun sunah yag diketahui latar belakag sosio-historisnya. Sedangkan pada kasus yang hanya bisa ditemuka teksnya sementara latar belakangnya tidak diketahui atau bahkan tidak ditemuka sama sekali teksnya, teori ini tidak dapat diterapkan. Hal ini diperkuat Rahman dengan pendapatnya bahwa ia sendiri menamakan usaha memahami Qur'an dengan metode Double Movement sebagai bentuk qiyas yang sesungguhnya. Sebagaimana diketahui bahwa qiyas hanya mungkin dilakukan ketika kasus hokum yang baru memiliki padanannya dengan teks wahyu. ${ }^{19}$

\section{Contoh Aplikasi}

Peraturan-peraturan hukum dan ketetapan pembaharuan umum yang paling penting dalam Qur'an ialah berhubungan dengan wanita dan budak. Qur'an melakukan perbaikan terhadap kedudukan wanita secara besar-besaran dalam berbagai segi dan yang paling pokok adalah bahwa wanita dianggap sebagai pribadi dengan jaminan

${ }^{19}$ Jamal Abdul Aziz, "Teori Gerakan Ganda: Metode baru istinbat hokum 'ala Fazlur Rahman”, Jurnal Hermeneuia (2007), 346, diakses 15 Juli 2018. 
penuh. ${ }^{20}$ Salah satu ayat al-Quran yang disoroti Rahman adalah ayat tentang poligami yang terdapat dalam Q.S al-Nisa'/04:03: ${ }^{21}$

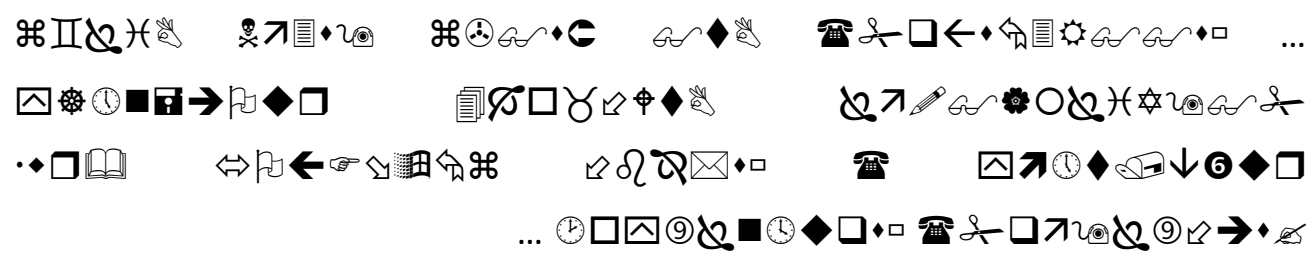

... Maka kawinilah wanita-wanita (lain) yang kamu senangi : dua, tiga atau empat. kemudian jika kamu takut tidak akan dapat Berlaku adil. Maka (kawinilah) seorang saja.... (Q.S an-Nisa'/04: 03).

Dalam berpoligami, terdapat syarat yang harus diperhatikan yakni berlaku adil. Syarat ini dalam pandangan Rahman sebenarnya merupakan indikasi kiasan untuk menggambarkan bahwa laki-laki tidak sanggup melakukannya. Selanjutnya, untuk memahami pesan al-Qur'an, perlu adanya penelusuran sosio-historis. Yakni kondisi bangsa Arab waktu itu banyak janda yang ditinggal mati suaminya dalam berperang sehingga banyak anak yang menjadi yatim. Tetapi dalam ayat selanjutnya yakni Q.S al-Nisa'/04: 129 disebutkan: ${ }^{22}$

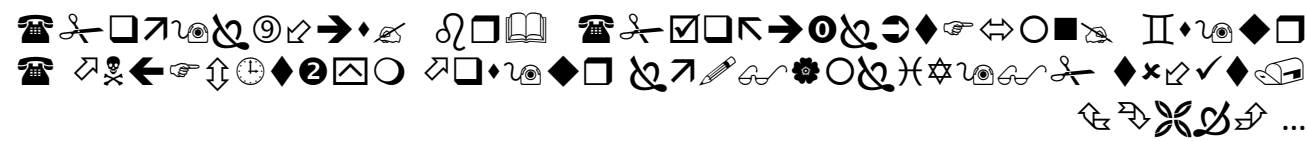
Dan kamu sekali-kali tidak akan dapat Berlaku adil di antara isteriisteri(mu), walaupun kamu sangat ingin berbuat demikian, ... (Q.S al-Nisa'/04: 129).

Dari ayat-ayat tersebut dapat dipahami bahwa sikap adil itu mustahil dijalankan oleh setiap orang laki-laki terhadap masingmasing istrinya. Berlaku adil dalam ayat ini harus diperhatikan,

\footnotetext{
${ }^{20}$ Fazlur Rahman, Islam terj. Senoaji Saleh, hlm. 59.

${ }^{21}$ Kementrian Agama RI, al-Qur'an Terjemah dan Tajwid, (Jakarta: SYGMA, 2014), hlm. 77.

${ }^{22}$ Kementrian Agama RI, al-Qur'an Terjemah dan Tajwid, hlm. 99.
} 
karena memiliki makna yang lebih mendasar dari pada alasan spesifik yang membolehkan poligami.

\section{Hadis Menurut Pandangan Fazlur Rahman}

\section{Hadis}

Fazlur Rahman mengartikan konsep "hadis” adalah ceritera, penuturan atau laporan, atau sebuah narasi singkat tentang apa yang dikatakan, dilakukan, disetujui atau tidak disetujui oleh Nabi, dan juga informasi yang sama mengenai para sahabat, dapa disebut juga Hadis merupakan refleksi verbal dari Sunnah yang hidup. Hadis ini diawali dari adanya sebuah ijtihad yang dilakukan oleh generasi pertama kaum Muslimin. ${ }^{23}$ Dan demikian pula Rahman menyimpulkan makna "sunnah" dalam tiga konsepsi yakni:

a. Sunnah ideal yaitu sunnah (tradisi praktikal) dan hadis (tradisi verbal) yang ada secara bersama dan memiliki subtansi yang sama. Keduanya disandarkan kepada Nabi dengan memperoleh normatifitasnya.

b. Living tradition (tradisi yang hidup), yakni berawal dari sunnah ideal yang telah mengalami penafsiarn sehingga menjadi praktek aktual kaum Muslim.

c. Adalah kesimpulan-kesimpulan yang ditarik dari kedua konsep. Yakni yang berhubungan dengan isi dari konsep sunah itu sendiri, karena tujuan dari konsep tersebut masih tetap kaitannya diarahkan kepada Nabi. Artinya dari sebuah hadis atau laporan sunnah berupa pokok norma praktis disimpulkan melalui penafsiran. ${ }^{24}$

Rahman menyatakan bahwa literatur hadis seharusnya tidak dianggap sebagai data sejarah yang dapat dipercaya dan dibuang secara

\footnotetext{
${ }^{23}$ Fazlur Rahman, Islam terj. Senoaji Saleh, hlm. 84.

${ }^{24}$ Abdul fatah Idris, "Studi Pemikiran Fazlur Rahman tentang hadis-hadis Prediktif dan Teknis" Jurnal, hlm. 3-4.
} 
keseluruhan. Meskipun bagian yang dianggap mewakili sunnah Nabi itu sedikit, sisanya mereflesikan sunnah yang hidup (living tradition) ${ }^{25}$ Hadis yang ditulis di dalam literatur hadis merupakan ungkapan verbalistis dari sunnah yang hidup, dan dijadikan sebuah bukti dokumen melalui jalur isnad (strand) yang disampaikan oleh seorang periwayat (common link), sampai pada penerima terakhir (kolektor), sekalipun hadis yang terhimpun itu sedikit atau keseluruhan merupakan hasil formalisasi para periwayat.

Sunnah yang hidup (living tradition) pada masa lalu tercermin dalam 'hadis' yang disertai dengan rangkaian periwayat. Adapun sisi perbedaan yang menonjol antara sunnah dan hadis, yaitu apabila secara umum sunnah merupakan suatu fenomena praktis yang ditujukan kepada norma-norma perilaku dan hukum, maka hadis tidak hanya menyampaikan norma-norma hukum tetapi juga keyakinan-keyakinan dan prinsip-prinsip religious.

\section{Pemahaman Hadis}

a. Hadis Hukum

Hadis-hadis hukum harus dipandang sebagai suatu masalah yang harus ditinjau kembali, dan bukan sebagai hukum yang sudah-jadi (ready-made law) yang harus diterapkan secara langsung. Rahman menawarkan bahwa hadis-hadis seperti itu harus diinterpretasikan menurut perspektif historisnya yang tepat dan situasi yang bersangkutan sehingga dari hadis tersebut dapat diambil kesimpulan hukumnya. Suatu hadis tidak seharusnya dipahami secara literal tanpa memperhatikan konteks situasionalnya. ${ }^{26}$

Adapun pemaknaan hadis-hadis hukum yang ditawarkan Rahman adalah melalui pendekatan historis-sosiologis. Pendekatan ini

\footnotetext{
${ }^{25}$ Fazlur Rahman, Islamic Methodology In History, hlm. 30

${ }^{26}$ Fazlur Rahman, Membuka Pintu Ijtihad (Bandung: Pustaka, 1995), hlm. 57.
} 
menjadi sangat penting karena setiap hadis termasuk hadis hukum selalu disertai dengan ratio legis (sasaran/tujuan hukum) yang menerangkan mengapa suatu hukum dinyatakan, sehingga hanya dengan memahami ratio legis dan latar belakang serta situasi yang terjadi pada Nabi dan umat Islam awal itulah umat Islam masa kini dapat menafsirkan hadis. ${ }^{27}$

Hadis-hadis teknis dipandang Fazlur Rahman sebagai hadis yang bukan bersumber dari nabi, tetapi tetap harus dipandang bersifat normatif di dalam formulasi-formulasinya yang aktual. Karena itu, hadis-hadis teknis tidak dikembalikan kepada Nabi. Tetapi hadishadis teknis merupakan hasil interpretasi yang kreatif dan dinamis terhadap sunnah Nabi, dan oleh karena itu dipandangnya sebagai indeks terhadap sunnah Nabi. Penolakan Rahman terhadap sebagian besar hadis-hadis teknis disebabkan karena hadis-hadis teknis itu merupakan hasil interpretasi dari sunnah Nabi kemudian hadis-hadis teknis harus dapat diinterpretasikan sesuai dengan situasi dan kondisi secara riil. ${ }^{28}$

Agar lebih jelas dan konkret, untuk mengetahui metode dan kajian historis-sosiologis serta kontekstual yang ditawarkan Rahman, dicontohkan praktek pembagian harta rampasan perang (ghanimah) yang dipraktekkan oleh Rasulullah Saw. Pada Perang Hunain, Rasulullah membagi harta rampasan lebih banyak untuk orang muallaf dari pada untuk orang Anshar. Tetapi pada masa Abu Bakar as-Shiddiq pembagian harta rampasan perang disamakan.

\footnotetext{
${ }^{27}$ Umma Farida, "Studi Pemikiran Fazlur Rahman tentang Sunnah dan Hadis" Jurnal ADDIN, (2013), 238, diakses: 20 Maret 2018.

${ }^{28}$ Abdul Fatah Idris, "Penolakan Fazlur Rahman terhadap hadis teknis pada hukum keperdataan", Jurnal Jurnal Wacana Hukum Islam dan Kemanusiaan, (2013), 196, diakses: 20 Maret 2018, doi: 10. 18326/ijtihad.v.13i2.179-197.
} 
Dengan pertimbangan orang muallaf karena dia masuk Islam pahalanya adalah dari Allah. Dan pertimbangan lain yaitu sebagai wadah kesediaan kaum Anshar untuk menerima Abu Bakar sebagai khalifah

Praktek di atas menunjukkan bahwa keputusan yang diambil Abu Bakar tetap mengacu pada sunah Nabi, tetapi Abu Bakar melakukan dan menafsirkan tindakan atau perilaku Nabi tersebut ketika menghadapi situasi dan kondisi yang baru dengan cara yang baru pula. Namun kedua praktek yang berbeda itu sama-sama memiliki tujuan yang sama, yakni kemaslahatan masyarakat pada waktu itu.

\section{b. Hadis Prediktif}

Rahman menyatakan bahwa ia tidaklah menolak semua hadishadis prediktif. Ia hanya menolak hadis-hadis prediktif yang bersifat spesifik. Hadis-hadis prediktif yang dimaksudkan Rahman tidaklah hadis-hadis yang berbentuk prediktif saja, melainkan juga yang mengandung prediksi (ramalan). Contoh hadis prediktif yang dimaksud Rahman adalah salah satunya diawali dengan kalimat " "seperti hadis dibawah ini: ${ }^{29}$

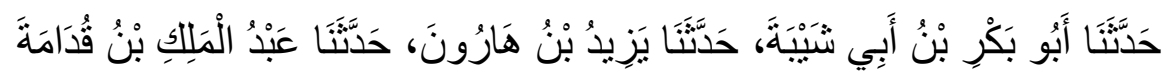

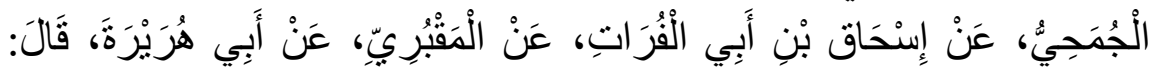

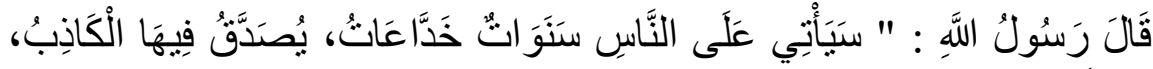

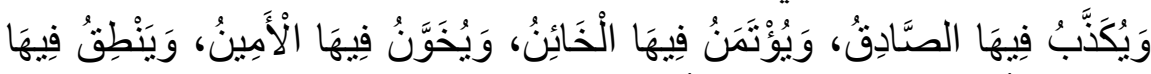

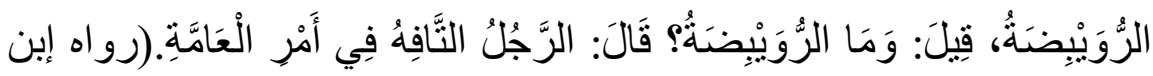

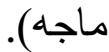

Dari Abu Bakri ibnu Abi Syaibah, dari Yazid bin Harun, dari 'Abdul Malik ibnu Kudamah al-Jumahiyyu, dari Ishak ibni Abi Furat, dari Makburiyyi, dari Abi Hurairah berkata: Rasulullah Saw

${ }^{29}$ Jawami'ul Kalim, Apilkasi Hadis “Abi Abdullah Muhammad bin Yazid alKhozwini, Sunan Ibnu Majjah", hlm. 980. 
bersabda: Akan datang suatu masa dimana orang berbohong dibenarkan, orang benar dianggap bohong, penghianat dipercaya dan orang yang dipercaya dihianati....... (H.R Ibnu Majjah).

Hadis Prediktif dimaksudkan Rahman tidaklah hadis-hadis yang berbentuk prediktif saja, melainkan juga yang mengandung prediksi (ramalan), ${ }^{30}$ seperti hadis:

"Orang-orang Qadariyah (orang-orang yang meyakini konsep kemerdekaan-kehendak manusia) adalah sebagai orang-orang Majusi di dalam umat ini".

Meski tidak bersifat prediktif secara langsung namun menurut Rahman, ${ }^{31}$ hadis ini mengandung prediksi, karena ia mengisyaratkan suatu kesadaran teknis di dalam pemikiran filosofis yang rumit. Suatu pemikiran yang tidak mungkin bersumber dari negeri Arab pada abad ketujuh. Argumentasi yang tersirat di dalam hadis ini adalah mengenai hal-hal berikut: Allah adalah Maha Kuat. Apabila ada sesuatu yang maha kuat maka tak sesuatu hal lain pun yang kuat, apalagi maha kuat. Tetapi agar memiliki kemerdekaan-berkehendak dan beraksi manusia harus memiliki kekuatan.

Hadis-hadis prediktif tidaklah memiliki historisitas, sehingga hadis-hadis seperti ini tidaklah ilmiah. Rahman yang dikutip oleh Farida menyatakan bahwa hadis seperti ini sangat sulit dinyatakan berasal dari Nabi Saw. Bahkan menurutnya, hadis ini hanya dapat terjadi ketika pemikiran umat Islam di bidang hukum dan mazhab-

\footnotetext{
${ }^{30}$ Fazlur Rahman, Membuka Pintu Ijtihad, 70

${ }^{31}$ Fazlur Rahman, Membuka Pintu Ijtihad, 97.
} 
mazhab hukum yang besar telah berkembang di seluruh pelosok dunia Islam. ${ }^{32}$

\section{E. Konstribusi Pemikiran Fazlur Rahman dalam Kajian Qur'an-Hadis}

Latar belakang intelektual Rahman yang menjadikan pemikirannya kritis dan dinamis telah memberikan banyak sumbangsih dalam kajian keislaman, terutama dalam kajian Qur'an-Hadis. Pemikiran Rahman dalam kajian Qur'an-Hadis selalu dihubungkan dengan keadaan historis dan konteks keadaan masyarakat zaman sekarang.

Melihat perkembangan zaman yang sangat kompleks dengan masalah-masalah kontemporer, menjadikan pemikiran Rahman sangat berguna dalam memahami kandungan Qur'an dan Hadis. Qur'an dan Hadis merupakan pedoman utama umat Islam. Maka seluruh aspek kegiatan umat Islam, harus berlandaskan pada kedua sumber tersebut. Ketika memahami kandungan Qur'an maupun Hadis, harus disesuaikan dengan keadaan lingkungan dan historis dimana kedua pedoman tersebut digunakan. Agar Qur'an dan Hadis tidak hanya merupakan teks yang mati, tetapi juga hidup sesuai dengan kondisi masyarakat yang berkembang.

Kajian Rahman tentang sunnah setidaknya telah mendobrak kebekuan metodologis pemikiran umat Islam dalam memahami sunnah/hadis Nabi dengan menganggap konsep sunnah Nabi sebagai konsep pengayom (general umbrella concept) yang senantiasa dinamis, dan tidak statis, yang pada akhirnya menjadikan pemikiran dan formula hukum Islam tidak lagi bernuansa atomistik dan skripturalistik.

\footnotetext{
${ }^{32}$ Umma Farida, Studi Pemikiran Fazlur Rahman tentang Sunnah dan Hadis" Jurnal ADDIN, (2013), 241, diakses: 20 Maret 2018.
} 
Pemahaman Hadis yang ditawarkan Rahman melalui pendekatan historis-sosiologis di atas akan menciptakan wacana baru, dinamis, dan kreatif sehingga ideal moral dari sunnah Nabi Saw. dapat direalisasikan secara progresif di dalam aneka ragam fenomena dan permasalahan sosial, sehingga hadis tidak lagi statis melainkan menjadi sunnah yang hidup. Melalui pendekatan historis-sosiologis ini pula, hadis akan menjadi 'pintu gerbang' bagi perumusan bangunan hukum Islam yang dinamis dalam rangka memenuhi kebutuhan hukum masyarakat yang senantiasa berubah.

Adanya konsepsi historisitas Qur'an yang tentu saja bertentangan dengan pendapat ortodoksi yang menempatkan Qur'an semata-semata sebagai kalam Tuhan dan menafikan dimensi historisnya, menjadikan Rahman mendapat kritik dan kecaman dari para ulama ortodoks tradisional, bahkan berujung pada pengusirannya dari Pakistan. Hal ini bisa dipahami karena dengan pemikiran tersebut Rahman berupaya menarik Qur'an dari wilayah transendental ke wilayah profan. ${ }^{33}$ Upaya ini cukup beralasan karena di tengah arus modernitas, ia menginginkan Qur'an tetap berperan aktif fungsional sebagai petunjuk moral dalam menghadapi kondisi dan problema-problem modernitas yang semakin komplek. Kondisi zaman yang berubah tentu saja menimbulkan tantangan yang berbeda, yang pada gilirannya membutuhkan jawaban-jawaban yang berbeda dengan yang diberikan Nabi Muhammad atau para ulama terdahulu.

\section{F. SIMPULAN}

Pemikiran Rahman dipengaruhi oleh dua corak pemikiran, yakni corak pemikiran barat dan tradisional. Pertama, latar belakang pendidikan

\footnotetext{
${ }^{33}$ Elya Munfarida, "Metodologi Penafsiran al-Qur'an menurut Fazlur Rahman", Jurnal Komunika, (2017), 248, diakses: 16 Maret 2018, doi: 10.24090.
} 
tradisional di bagian timur Pakistan dan latar belakang pendidikan modern Barat Inggris. Kedua, kombinasi latar belakang karir intelektual bersama piha konservatif di Pakistan dan latar belakang intelektual bersama pihak liberal di Chicago. Dari kedua latar belakang yang berbeda tersebut melahirkan pemikiran Rahman yang moderat, sintesis dan metodis.

Rahman memahami Qur'an sebagai sebuah kitab yang berisi prinsipprinsip keagamaan dan moral bukan sebagai suatu dokumen hukum. Qur'an adalah pedoman pertama umat Islam. Oleh karena itu, Qur'an harus dipahami sesuai perkembangan dan disesuaikan dengan masalahmasalah baru yang terjadi di masyarakat terutama disesuaiakn dengan pembinaan dan perbaikan moral. Dalam memahami Qur'an, Rahman memiliki teori yang disebut teori Double Movement dalam menginterpretasikan kandungan dan makna Qur'an sesuai kebutuhan dan perkembangan zaman.

Selanjutnya hadis, merupakan sumber pedoman kedua setelah Qur'an. Rahman membedakan definisi hadis dan sunah, meskipun keduanya masih memiliki persamaan. Dipahami oleh Rahman Hadis sebagai ungkapan verbalistis dari sunnah yang hidup, dan dijadikan sebuah bukti dokumen melalui jalur isnad (strand) yang disampaikan oleh seorang periwayat (common link).

\section{DAFTAR PUSTAKA}

Abdul Fatah Idris, "Penolakan Fazlur Rahman terhadap hadis teknis pada hukum keperdataan", Jurnal Jurnal Wacana Hukum Islam dan Kemanusiaan, (2013), 196, diakses: 20 Maret 2018, doi: 10. 18326/ijtihad.v.13i2.179-197.

Ajahari, "Pemikiran Fazlur Rahman Dan Muhammad Arkoun" Jurnal Sudi Agama dan Masyarakat, (2016), 238-239, diakses: 17 Maret 2018. 
Aziz, Jamal Abdul "Teori Gerakan Ganda: Metode baru istinbat hukum 'ala Fazlur Rahman”, Jurnal Hermeneuia (2007), 346, diakses 15 Juli 2018.

Elya Munfarida, "Metodologi Penafsiran al-Qur'an menurut Fazlur

Rahman", Jurnal Komunika, (2017), 248, diakses: 16 Maret 2018, doi: 10.24090 .

Mirawati, "Thinking Of Fazlur Rahman About Islamic Education" Al-Manar Journal Of Education And Islamic Studies (2014), 82, diakses 17 Maret 2018.

Rifki Ahda Sumantri, “Hermeneutika al-Qur'an Fazlur Rahman Metode Tafsir Doubel Movement" Jurnal Komunika, (2015), 4, diakses: 17 Maret 2018, doi: 10.24090/kom.v7i1.2013.pp\%p.

Ulya, "Hermeneutika Double Movement Fazlur Rahman Menuju Peneapan Hukum Bervisi Etis", Jurnal Ulul Albab (2013), 9-10, diakses: 16 Maret 2018, doi: 10. 18860/ua.v0I0.2385.

Umma Farida, "Studi Pemikiran Fazlur Rahman tentang Sunnah dan Hadis" Jurnal ADDIN, (2013), 238, diakses: 20 Maret 2018.

\section{Sumber Buku}

Amal, Islam Dan Tantangan Modernitas Studi Pemikiran Hukum Fazlur Rahman, Bandung: Penerbit Mizan, 1993.

Assa'idi, Sa'dullah Pemahaman Tematik al-Qur'an Menurut Fazlur Rahman, Jakarta: Pustaka Pelajar, 2013.

Kementrian Agama RI, al-Qur'an Terjemah dan Tajwid, Jakarta: SYGMA, 2014.

Mawardi, "Hermeneutika al-Qur'an Fazlur Rahman" dalam Hermeneutika al-Qur'an dan Hadis, Yogyakarta: eLSAQ, 2010.

Mustaimtaqim, Abdul, Epistemologi Tafsir Kontemporer, Jakarta: LKiS, 2010.

Nasir, Sahilun A Pemikiran Kalam Teologi Islam, Jakarta: Raja Grafindo Persada, 2010.

Rahman, Fazlur, Islam and Modernitas: Tranformation of An Intellectual Tradition, (Chicago and London: Univercity Press, 1982.

-----, Islam and Modernity, PDF BOOK London: Chicago press, 1982. 
-----, Islam terj. Senoaji Saleh, Jakarta: Bumi Aksara, 1992.

-----, Islamic in Methodology and History, PDF BOOK, Pakistan: Islamic Research Institute's , t.t.

-----, Major Themes of the Qur'an, PDF-BOOK Chichago: minneo-apolisBiblioeca Islamica, 1980.

-----, Membuka Pintu Ijtihad, Bandung: Pustaka, 1995.

-----, Cita-cita Islam. Terjemahan Sufyanto dan Imam Musbikin. Yogyakarta: Pustaka Pelajar, 2000.

Sholeh, Ahmad Syukri, Metodologi Tafsir Al-Qur'an Kontemporer dalam Pandangan Fazlur Rahman, Jakarta: Gaung Persada Press, 2007.

Supena, Ilyas, Desain Ilmu-ilmu Keislaman dalam Pemikiran Hermeneutika Fazlur Rahman, Semarang: Walisongo Press, 2008.

Jawami'ul Kalim, Apilkasi Hadis "Abi Abdullah Muhammad bin Yazid alKhozwini, Sunan Ibnu Majjah". 